\title{
Characterization of women victims of violent death in a metropolitan area of Northeast Brazil
}

\author{
Caracterização de mulheres vítimas de morte violenta na região metropolitana de uma cidade do Nor- \\ deste
}

Maria da Conceição Andrade de OLIVEIRA'

Elvio Luís Ramos VIEIRA ${ }^{1}$

Marcel Rolland Ciro da PENHA ${ }^{2}$

Eduardo Henriques de MELO3

Arnaldo de França CALDAS JUNIOR ${ }^{4}$

\section{ABSTRACT}

\section{Objective}

To analyze the frequency, body topographic local and the instruments used in women with violent death in the city of Recife and the metropolitan area and in the years from 2000 to 2009.

\section{Methods}

Data collection was performed at the Institute of Forensic Medicine Persivo Antonio Cunha-PE from March to October 2010. Through a study, of chronological approach, necropsy reports in women residing in the Metropolitan Region of Recife-PE in the years 2000 to 2009 were selected. We analyzed the frequency of deaths, the type of instruments used and the topographic location of the lesion. Statistical analysis used the chi-square test or Fisher's exact test, at the significance level of 5\%.

\section{Results}

The frequency distribution showed that the homicide was the 1st reason and represented $36.2 \%$ of the total mortality. The accident was the second most common cause with 30.2\% followed by the suicides with $5.7 \%$. Regarding the body topographic location, polytrauma presented $29.1 \%$ of the occurrences followed by the craniofacial complex with $26.3 \%$. Within the complex craniofacial, the head was the most affected with $27.4 \%$. The face corresponded to $4.2 \%$ of the cases. The type of instrument of more incidence was the blunt with $36 \%$, followed by blunt-stabbing with $27 \%$.

\section{Conclusion}

The homicides demonstrate the magnitude of external causes as cause of premature death among women. The head and neck region is closely linked to the cases of violence against women.

Indexing terms: Public health. Violence. Violence against women.

\section{RESUMO}

\section{Objetivo}

Analisar a frequência, a localização topográfica corporal e o instrumento utilizado em mulheres com morte violenta na cidade de Recife e Região Metropolitana nos anos de 2000 a 2009.

\section{Métodos}

A coleta de dados foi realizada no Instituto de Medicina Legal Antonio Persivo Cunha, Pernambuco entre março a outubro de 2010 . Por meio de um estudo, de série temporal foram selecionados os Laudos necroscópicos, realizados entre os anos de 2000 a 2009 em mulheres residentes na Região Metropolitana do Recife, Pernambuco. Foram analisados a frequência dos óbitos, o tipo de instrumento utilizado e a localização topográfica da lesão. Na análise estatística utilizou-se o Qui-quadrado de Pearson ou Exato de Fisher, a um nível de significância de $5 \%$.

\section{Resultados}

A distribuição de frequência mostrou que o homicídio foi a $1^{\text {a }}$ razão e representou $36,2 \%$ da mortalidade total. Os acidentes representaram a segunda causa mais frequente com $30,2 \%$ seguida dos suicídios 5,7\%. Em relação à localização topográfica corporal os politraumatismos apresentaram 29,1\% de ocorrência seguido do complexo crânio-facial com 26,3\%. Dentro do complexo crânio-facial a cabeça foi a mais atingida com $27,4 \%$. A face apresentou $4,2 \%$ dos casos. O tipo de instrumento mais utilizado foi o contudente com $36 \%$, seguido pelo perfuro-contundente com $27 \%$.

\section{Conclusão}

Os homicídios demonstram a magnitude das causas externas como causa de morte prematura entre as mulheres. A região da cabeça e pescoço esta intimamente ligada aos casos de violência contra a mulher.

Termos de indexação: Saúde pública. Violência. Violência contra a mulher.

\footnotetext{
${ }^{1}$ Universidade de Pernambuco, Faculdade de Odontologia. Av. Gal. Newton Cavalcanti, 1650, 54753-020, Camaragibe, PE, Brasil. Correspondência para / Correspondence to: MCA OLIVEIRA. E-mail: <mcao.odonto@gmail.com>.

${ }^{2}$ Hospital Universitário Oswaldo Cruz. Recife, PE, Brasil.

${ }^{3}$ Associação Caruaruense de Ensino Superior. Recife, PE, Brasil.

${ }^{4}$ Universidade Federal de Pernambuco. Recife, PE, Brasil
} 


\section{INTRODUCTION}

Since the 90s, violence against women has been recognized as a problem of public health and a violation of the human rights, considering their magnitude and impact on health'.

The violence of man against their peers dates from the early days of humanity's history. According to the Freudian psychoanalytic theory, there is in humans, since their childhood, an innate polymorphous perverse disposition. It is necessary to understand that women who are victims of violence are social subjects who carry in themselves the cultural gender characteristics which compose a social construct, and that has placed the man in a condition of domination over women throughout history ${ }^{2}$.

Since the ancient civilizations females suffer from the social domination that has been imposed by the males. In the present days it is still possible to perceive these characteristics, like in many peoples around the world, where we can even find some extreme restrictions. In some countries women do not have birth or death certificates, and can be subjected to corporal chastisement without any punishment to their aggressor ${ }^{3}$.

Violence against women, in Brazil, is a matter of public health, as the large number of victims it reaches and its deleterious effects on physical and mental health, as well as by its economic consequences for the country. In Brazil, every minute a woman is assaulted and currently $23 \%$ of the women suffer domestic violence ${ }^{4}$.

The high levels of violence against women through psychological aggression, bodily injury or homicide, and also public policies to combat these forms of crime sensitize and lead scholars to discuss the topic in an attempt to understand what motivates and leads individuals to consummate such offenses, in order to forestall and prevent this fatality that emerges from society and marks the contemporary, claiming lives. The violence is an increased risk for the realization of the vital process: it threatens life, changes health, produces illness and causes death as a reality or as the next possibility ${ }^{5}$.

Several studies highlight the geographical distribution of the bodily injuries in abused women ${ }^{6}$. Many of these aggression are to the women's face, corroborating the importance of a study of the lesions and the instrument types, to better understand the effects and psychological consequences for the victim.

Despite the significant progresses made in this area, such as the fact that it has been nearly 30 years since the implementation of relevant public policies to combat domestic violence, the Special Police Offices for the Assistance of Women, and the declaration of constitutionality of Maria da Penha's Law in February 2012, several points about the reality of such violence and the legal, the government and the civil society mechanisms created to deal with such problems remain as a challenge, particularly due to the enormous diversity of women's groups in the country?

Considering the importance of the increasing number of women's deaths due to violence, we have analyzed the frequency of these deaths, the location of the lesions and the types of instrument used in women victims of violent death in the metropolitan area of Recife $(\mathrm{PE})$, emphasizing, therefore, the importance of statistics on mortality that can and must guide the decision-making in health care.

\section{METHODS}

The study was conducted in 2010 in the city of Recife, capital of Pernambuco.

The studied population consisted of women living in the metropolitan area of Recife who died due to injuries caused by violent death and then subjected to autopsies in the Institute of Forensic Medicine Persivo Antonio Cunha from 2000 to 2009.

The study material was the totality of necroscopic reports of women whose deaths were due to unnatural causes occurred in the period from 2000 to 2009 in the Metropolitan Region of Recife.

After the women's data collection, according to the craniofacial injury, it was verified: the type of instrument used $^{8}$ and the location of the craniofacial injury ${ }^{9}$.

The data involved the obtaining measurements: mean, standard deviation, median and percentage calculation. To assess the association between two variables we used Pearson's chi-square test or Fisher's exact test when the application of the chi-square test could not be validated. The margin of error for statistic tests was $5.0 \%$.

\section{RESULTS}

The ages of the necropsied women were analyzed and ranged from 1 to 102 years. The average age was 38.04 years, and the median 33.00 years. The standard deviation was 21.95 years.

Table 1 highlights the highest percentages of women killed in 2008 (12.6\%) and 2009 (12.1\%). 
Table 1. Distribution of the study subjects according to the year of their death.

\begin{tabular}{lcc}
\hline Year of death & $\mathbf{n}$ & $\%$ \\
\hline 2000 & 320 & 9.4 \\
2001 & 187 & 5.5 \\
2002 & 291 & 8.5 \\
2003 & 322 & 9.4 \\
2004 & 338 & 9.9 \\
2005 & 385 & 11.3 \\
2006 & 342 & 10.0 \\
2007 & 387 & 11.3 \\
2008 & 429 & 12.6 \\
2009 & 412 & 12.1 \\
Total & 3413 & 100 \\
\hline
\end{tabular}

In the specific group of external causes, homicide was the most frequent cause of death in the population studied, and it comprises 1236 cases (36.2\%). Accidents represented the second most frequent cause with 1030 cases $(30.2 \%)$. Among the cases of Suicide, there were 193 events $(5.7 \%)$.
Table 2. Distribution of women's deaths frequencies caused by external causes and classified as homicide, suicide, accident and undetermined intention event. Recife (2000-2009).

\begin{tabular}{lcc}
\hline Death cause & $\mathbf{n}$ & $\%$ \\
\hline Murder & 1236 & 36.2 \\
Suicide & 193 & 5.7 \\
Accident & 1030 & 30.2 \\
Undertermined & 954 & 28.0 \\
Total & 3413 & 100 \\
\hline
\end{tabular}

Table 3 shows that in the age group up to 9 years of age there were more frequently accidents. The age group from 10 years old until 49 years old, there was a higher frequency of homicides. In the group from 50 years old up to 80 years old or more occurred more accidents. Suicide was more frequent in the age group of 50 to 59 years of age.

For the women living in Recife there was a greater frequency of homicides (37.1\%), and the same occurred in the metropolitan area (35.6\%).

Table 3. Evaluation of the death causes according to each of the variables: age and place of residence.

\begin{tabular}{|c|c|c|c|c|c|c|c|c|c|c|c|}
\hline \multirow{3}{*}{ Variables } & \multicolumn{10}{|c|}{ Cause of death } & \multirow{3}{*}{$P$ value } \\
\hline & \multicolumn{2}{|c|}{ Murder } & \multicolumn{2}{|c|}{ Suicide } & \multicolumn{2}{|c|}{ Accident } & \multicolumn{2}{|c|}{ Unknown } & \multicolumn{2}{|c|}{ Total } & \\
\hline & $\mathrm{n}$ & $\%$ & $\mathrm{n}$ & $\%$ & $\mathrm{n}$ & $\%$ & $\mathbf{n}$ & $\%$ & $\mathrm{n}$ & $\%$ & \\
\hline \multicolumn{12}{|c|}{ - Age range (years) } \\
\hline Up to 4 & 7 & 7.2 & - & - & 49 & 50.5 & 41 & 42.3 & 97 & 100 & \\
\hline 5 to 9 & 11 & 13.6 & - & - & 44 & 54.3 & 26 & 32.1 & 81 & 100 & \\
\hline 10 to 14 & 61 & 42.1 & 4 & 2.8 & 54 & 37.2 & 26 & 17.9 & 145 & 100 & \\
\hline 15 to 19 & 217 & 54.7 & 28 & 7.1 & 70 & 17.6 & 82 & 20.7 & 397 & 100 & \\
\hline $20-29$ & 430 & 54.9 & 51 & 6.5 & 168 & 21.5 & 134 & 17.1 & 783 & 100 & \\
\hline 30 to 39 & 248 & 47.5 & 26 & 5.0 & 125 & 23.9 & 123 & 23.6 & 522 & 100 & $p(1)<0.001$ * \\
\hline 40 to 49 & 153 & 33.9 & 35 & 7.8 & 123 & 27.3 & 140 & 31.0 & 451 & 100 & \\
\hline 50 to 59 & 67 & 22.0 & 25 & 8.2 & 98 & 32.2 & 114 & 37.5 & 304 & 100 & \\
\hline 60 to 69 & 19 & 8.9 & 16 & 7.5 & 95 & 44.4 & 84 & 39.3 & 214 & 100 & \\
\hline 70 to 79 & 11 & 4.9 & 7 & 3.1 & 116 & 51.6 & 91 & 40.4 & 225 & 100 & \\
\hline 80 or more & 12 & 6.2 & 1 & 0.5 & 88 & 45.4 & 93 & 47.9 & 194 & 100 & \\
\hline Total & 1236 & 36.2 & 193 & 5.7 & 1030 & 30.2 & 954 & 28.0 & 3413 & 100 & \\
\hline \multicolumn{12}{|c|}{ - Place of residence } \\
\hline Recife & 548 & 37.1 & 97 & 6.6 & 413 & 27.9 & 421 & 28.5 & 1479 & 100 & $p(1)=0.030$ * \\
\hline MRR & 688 & 35.6 & 96 & 5.0 & 617 & 31.9 & 533 & 27.6 & 1934 & 100 & \\
\hline Total & 1236 & 36.2 & 193 & 5.7 & 1030 & 30.2 & 954 & 28.0 & 3413 & 100 & \\
\hline
\end{tabular}

In most of the deaths, the number of the affected areas in the body varied from the craniofacial complex to polytrauma.
The highest percentage corresponded to politrauma (29.1\%), followed by the craniofacial complex (26.3\%). 
Table 4. Distribution of the study subjects according to the variables: means used, type of instrument and body topographic location.

\begin{tabular}{|c|c|c|}
\hline Variable of the study & $\mathbf{n}$ & $\%$ \\
\hline \multicolumn{3}{|l|}{ The means applied } \\
\hline Mechanical & 2300 & 67.4 \\
\hline Physical & 184 & 5.4 \\
\hline Chemical & 134 & 3.9 \\
\hline Physical-Chemical & 227 & 6.7 \\
\hline Ignored & 568 & 16.6 \\
\hline \multicolumn{3}{|l|}{ Type of instrument } \\
\hline Stabbing & 1 & 0.0 \\
\hline Cutting & 5 & 0.1 \\
\hline Blunt & 1230 & 36.0 \\
\hline Stabbing / Cutting & 117 & 3.4 \\
\hline Stabbing / Blunt & 920 & 27.0 \\
\hline Cut / blunt & 25 & 0.7 \\
\hline Associated & 7 & 0.2 \\
\hline Ignored & 1108 & 32.5 \\
\hline \multicolumn{3}{|l|}{ Body topographic location } \\
\hline Cranio-facial complex & 897 & 26.3 \\
\hline Upper body & 426 & 12.5 \\
\hline Members & 61 & 1.8 \\
\hline Polytrauma & 994 & 29.1 \\
\hline Ignored & 1035 & 30.3 \\
\hline \multicolumn{3}{|l|}{ Craniofacial region } \\
\hline Face & 144 & 4.2 \\
\hline Cranium & 598 & 17.5 \\
\hline Neck & 150 & 4.4 \\
\hline Head & 936 & 27.4 \\
\hline Not applicable & 550 & 16.1 \\
\hline Ignored & 1035 & 30.3 \\
\hline Total & 3413 & 100 \\
\hline
\end{tabular}

In the craniofacial complex, the head was the most affected area (27.4\%), followed by the cranium (17.5\%). The instruments most commonly used in cases of aggression were blunt (36.0\%), followed by stabbing-blunt (27.0\%).

The mechanical means was the one that presented a greater percentage (67.4\%), followed by the chemical-physical (7.7\%), physical (5.4\%) and chemical (3.9\%) (Table 5).

Table 4 shows that the mechanical means was the most used in the homicide cases $(50.5 \%)$. The physical means is present in the accidents $(46.2 \%)$, The chemical in suicide cases $(64.9 \%)$ and the physical and chemical in the case of accidents (33.9\%).

Among the causes of death, cutting instruments (100\%), stabbing-cutting (94.5\%), stabbing-blunt
(94.5\%) and cutting-blunt (88.0\%) were the most used in cases of homicides. The blunt instruments $(67.3 \%)$ were the most used in the cases of accidents and the association of instruments $(7.4 \%)$ in cases of murder.

Regarding the topographical location of the injuries, the craniofacial complex was the most affected in cases of homicide(58.3\%). The same occurring in the upper body (64.3\%). The members were the most affected in the event of accidents (55.7\%) and the same occurred with polytrauma $(48.8 \%)$

The region of the face was the most affected in cases of homicide $(87.5 \%)$, and so was the cranium $(59.5 \%)$ and the neck $(69.3 \%)$. The head was the most affected in accidents (53.2\%). 
Table 5. Evaluation of the death causes according to the variables: means used, types of instrument, topographic location and craniofacial region.

\begin{tabular}{|c|c|c|c|c|c|c|c|c|c|c|c|}
\hline \multirow{3}{*}{ Variables } & \multicolumn{10}{|c|}{ Death causes } & \multirow{3}{*}{$P$ value } \\
\hline & \multicolumn{2}{|c|}{ Homicide } & \multicolumn{2}{|c|}{ Suicide } & \multicolumn{2}{|c|}{ Accident } & \multicolumn{2}{|c|}{ Ignored } & \multicolumn{2}{|c|}{ TOTAL } & \\
\hline & $\mathbf{n}$ & $\%$ & $\mathbf{n}$ & $\%$ & $\mathbf{n}$ & $\%$ & $\mathbf{n}$ & $\%$ & $\mathbf{n}$ & $\%$ & \\
\hline \multicolumn{12}{|l|}{ The means used } \\
\hline Mechanical & 1161 & 50.5 & 42 & 1.8 & 840 & 36.5 & 257 & 11.2 & 2300 & 100 & \\
\hline Physical & 7 & 3.8 & 15 & 8.2 & 85 & 46.2 & 77 & 41.8 & 184 & 100 & \\
\hline Chemical & 2 & 1.5 & 87 & 64.9 & 3 & 2.2 & 42 & 31.3 & 134 & 100 & $p(1)<0.001$ * \\
\hline Physical-Chemical & 44 & 19.4 & 26 & 11.5 & 77 & 33.9 & 80 & 35.2 & 227 & 100 & \\
\hline Ignored & 22 & 3.9 & 23 & 4.0 & 25 & 4.4 & 498 & 87.7 & 568 & 100 & \\
\hline Total & 1236 & 36.2 & 193 & 5.7 & 1030 & 30.2 & 954 & 28.0 & 3413 & 100 & \\
\hline \multicolumn{12}{|l|}{ Type instrument } \\
\hline Piercing & - & - & - & - & - & - & 1 & 100 & 1 & 100 & \\
\hline Cutting & 5 & 100 & - & - & - & - & - & - & 5 & 100 & \\
\hline Scathing & 148 & 12.0 & 31 & 2.5 & 828 & 67.3 & 223 & 18.1 & 1230 & 100 & \\
\hline Punch-cutting & 111 & 94.9 & 2 & 1.7 & 1 & 0.9 & 3 & 2.6 & 117 & 100 & (2) $\cap 001$ * \\
\hline Punch-blunt & 869 & 94.5 & 11 & 1.2 & 9 & 1.0 & 31 & 3.4 & 920 & 100 & (1) $<1<0.001$ \\
\hline Cut-blunt & 22 & 88.0 & - & - & 1 & 4.0 & 2 & 8.0 & 25 & 100 & \\
\hline Unknown & 76 & 6.9 & 148 & 13.4 & 190 & 17.1 & 694 & 62.6 & 1108 & 100 & \\
\hline Associate & 5 & 7.4 & 1 & 14.3 & 1 & 14.3 & - & - & 7 & 100 & \\
\hline Total & 1236 & 36.2 & 193 & 5.7 & 1030 & 30.2 & 954 & 28.0 & 3413 & 100 & \\
\hline \multicolumn{12}{|c|}{ Body topographic location } \\
\hline $\begin{array}{l}\text { Cranio-facial } \\
\text { complex }\end{array}$ & 523 & 58.3 & 26 & 2.9 & 215 & 24.0 & 133 & 14.8 & 897 & 100 & \\
\hline Upper body & 274 & 64.3 & 6 & 1.4 & 108 & 25.4 & 38 & 8.9 & 426 & 100 & \\
\hline Members & 2 & 3.3 & 1 & 1.6 & 34 & 55.7 & 24 & 39.3 & 61 & 100 & $p(1)<0.001$ * \\
\hline Polytrauma & 401 & 40.3 & 25 & 2.5 & 485 & 48.8 & 83 & 8.4 & 994 & 100 & \\
\hline Ignored & 36 & 3.5 & 135 & 13.0 & 188 & 18.2 & 676 & 65.3 & 1035 & 100 & \\
\hline Total & 1236 & 36.2 & 193 & 5.7 & 1030 & 30.2 & 954 & 28.0 & 3413 & 100 & \\
\hline \multicolumn{12}{|c|}{ Craniofacial region } \\
\hline Face & 126 & 87.5 & 3 & 2.1 & 9 & 6.3 & 6 & 4.2 & 144 & 100 & \multirow{6}{*}{$p$ (1) $<0.001$ * } \\
\hline Cranium & 356 & 59.5 & 6 & 1.0 & 162 & 27.1 & 74 & 12.4 & 598 & 100 & \\
\hline Neck & 104 & 69.3 & 18 & 12.0 & 7 & 4.7 & 21 & 14.0 & 150 & 100 & \\
\hline Head & 309 & 33.0 & 21 & 2.2 & 498 & 53.2 & 108 & 11.5 & 936 & 100 & \\
\hline Not applicable & 305 & 55.5 & 10 & 1.8 & 166 & 30.2 & 69 & 12.5 & 550 & 100 & \\
\hline Ignored & 36 & 3.5 & 135 & 13.0 & 188 & 18.2 & 676 & 65.3 & 1035 & 100 & \\
\hline Total & 1236 & 36.2 & 193 & 5.7 & 1030 & 30.2 & 954 & 28.0 & 3413 & 100 & \\
\hline
\end{tabular}

Note: $(P<0.05)$ : Significant difference at the level of 5.0\%. (1) According to Pearson's chi-square test. (2): According to Fisher's exact test

\section{DISCUSSION}

Based on the subdivision of the external causes, the homicides in our study represented $36.2 \%$ of the deaths. In 1998 , this death cause was responsible for $16 \%$ of the cases in developing countries ${ }^{10}$. In Brazil, according to the Latin American Center for Studies of Violence in 2000 homicides made 45,343 cases, which is equivalent to $38.9 \%$ of deaths from external causes and $4.8 \%$ of total deaths countrywide. In this study the death rate increased by $115 \%$, moving from 12 deaths/10000 to $27 / 10000$, The behavior according to the gender showed that both female mortality as the male had statistically significant growth, increasing by $120 \%$ between men and $82 \%$ among women. 
In Brazil between 1979 and 1999 the data for mortality from specific external causes classify traffic accidents as the leading cause of death among women, as it presents death rates cause by traffic accidents of $8 / 10000$ women ${ }^{11}$. In this study accidents occupied the first position in 2008 and 2009, with $31.1 \%$ and $33.2 \%$ respectively.

In Brazil 30,000 people die each year in traffic accidents; 44\% aged between 20 and 39 years; 82\% are male ${ }^{12}$. Looking more closely at the female mortality from external causes it is observed that traffic accidents represent an important part of their mortality $(26 \%)^{13}$.

Suicides have appeared in our work as the third cause of death with frequency of $5.7 \%$, considering the main cause of death from external causes. Corroborating our study a survey on suicides in Brazil in 2000 found the occurrence of 6,778 deaths, corresponding to $5.7 \%$ of the total of deaths in te country.

Different findings were highlighted by the World Health Organization ${ }^{14}$, in a report where in high-income countries suicide is the leading cause of violent death and that in 2000 this cause accounted for nearly half of all deaths in the United States.

The percentage of aggression in the head area differs depending on the author or the collection site of the study. In Rio de Janeiro it was found $37.7 \%$; in Joao Pessoa $50.8 \%{ }^{3}$; in Sao Paulo $54.6 \%{ }^{4}$ and $69.8 \%$ in Mexico ${ }^{15}$. In the present study the craniofacial complex represented $26.3 \%$ of the lesions, showing high percentage in the region of the head $(27.4 \%)$. In many cultures, the face is the place that reveals the honor.Thus, hitting on the face demands submission and the "shining face" is highly significant ${ }^{16 .}$

Regarding the occurrence of head injuries, it was observed that $25.9 \%$ corresponded to the lip region (face) mentonian (face) and buccinator (face); $22.2 \%$

\section{REFERENCES}

1. Watts C, Zimmerman C. Violence against women global scope and magnitude. Lancet. 2002;359(9313):1232-7. doi: 10.1016/ S0140-6736(02)08221-1

2. Ribeiro CG, Coutinho MLL. Representações sociais de mulheres vítimas de violência doméstica na cidade de João Pessoa-PB. Rev Psicol Saúde. 2011;3(1):52-9.

3. Rabello PM, Leite ICC, Alves JJS, Alves NSS, Silva RM, Félix SSS. Importância do Odontolegista no exame de corpo de delito, 460 casos de mulheres agredidas, DML, João Pessoa-PB. Rev Saude Etica Just. 1998;3(1/2):25-32. corresponded to the orbital (face), the frontal (cranium) $11.5 \%^{3}$. In another study the regions most affect were the orbital (Face) and the mandible (Face). A similar result was found in this work where the face region was the most affected in cases of homicide $(87.5 \%)^{6}$.

The lesions in the temporal region (cranium) were observed in this study and shows the cranium, as part of the craniofacial complex with $17.5 \%$ occurrences. Similar results were found in other studies in which the region of the upper members are the most affected ${ }^{17-18}$. The lesions on the upper body (face, neck and arms) confirms not only the attempt of protection from the aggression, but also the intention of the perpetrator in humiliating and assaulting the dignity of women ${ }^{18}$.

\section{CONCLUSION}

The metropolitan area of Recife, including its capital, is known to be violent, where violence towards vulnerable groups such as children, adolescents and women have increased alarmingly.

This article has endorsed that the crimes against women are on the rise and it is important for trying to better understand the many different facets of this framework that are essential for the establishment of public policies that can prevent this escalating levels of violence.

\section{Collaborators}

MCA OLIVEIRA worked in the analysis, data interpretation and writing of the article. EH MELO worked in conception and final writing. ACF CALDAS JUNIOR worked in the critical review and writing of the article. MRC PENHA and ELR VIEIRA worked in the field of research and writing of this article. 
8. Vanrell JP. Odontologia legal \& antropologia forense. Rio de Janeiro: Guanabara Koogan; 2002.

9. França GV. Medicina Legal. Rio de Janeiro: Guanabara Koogan; 1995.

10. World Health Organization (WHO). The world health report 2001. [acesso em 05 de Novembro de 2013]. Disponível em: <http://www.who.int/whr/2001/charper2/en/index6.html>.

11. Peres MFT. Violência por armas de fogo no Brasil: relatório Nacional. São Paulo: Organização Pan-Americana da Saúde; 2004.

12. Peden M. Informe mundial sobre prevención de los traumatismos causados por el tránsito. Genebra: Organización Mundial de la Salud; 2004.

13. Galdino RE, Mamer ICP. De que morrem as mulheres brasileiras Associação Brasileira de Estudos Populacionais - ABEP [citado 2013 Set 13]. Disponível em: < http://www.abep.nepo.unicamp. br/docs/anais/pdf/2002/GT_SAU_ST35_Godinho_texto.pdf>.

14. Organização Mundial de Saúde (OMS). Relatório mundial sobre violência e saúde. Genebra: Organização Mundial da Saúde; 2002.
15. Medina HM, Regata LF, Santiago RV, Blanco J. Atención médica de lesiones intencionales provocadas por la violência familiar. Salud Pública Méx. 2003;45(4):252-8

16. Costa A, Bruschini C. (org.). Uma questão de gênero. Rio de Janeiro: Rosa dos Tempos/FCC; 1987

17. Alvarado-Zaldívar G, Salvador-Moysén J, Estrada-Martínez SE, Terrones-Gonzáles. A. Prevalência de violencia doméstica en la ciudad de Durango. Salud Publica. 1998;40(6):481-6. doi: 10.1590/S0036-36341998000600004

18. Ilha MM, Leal, SMC, Soares JSF. Mulheres internadas por agressão em um hospital de pronto socorro: (in)visibilidade da violência. Rev Gaúch Enf. 2010;31(2):328-34.

Received on: 6/10/2014

Final version resubmitted on: 10/12/2014

Approved on:18/6/2015 